\title{
Improved management of Vertisols in the semiarid tropics for increased productivity and soil carbon sequestration
}

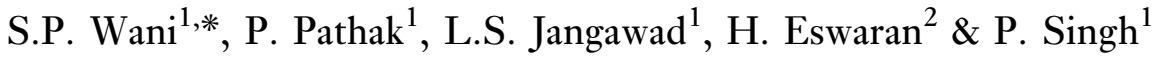

\begin{abstract}
This study was undertaken to test the hypothesis that an improved system of catchment management in combination with appropriate cropping practices can sustain increased crop production and improve soil quality of Vertisols, compared with prevailing traditional farming practices. Initiated in 1976, the improved system consisted of integrated land management to conserve soil and water, with excess rainwater being removed in a controlled manner. This was combined with improved crop rotation (legume based) and integrated nutrient management. In the traditional system, sorghum or chickpea was grown in the postrainy season with organic fertilizers, and in the rainy season the field was maintained as a cultivated fallow. The average grain yield of the improved system over 24 years was $4.7 \mathrm{tha}^{-1} \mathrm{yr}^{-1}$, nearly a five-fold increase over the traditional system (about $1 \mathrm{tha}^{-1} \mathrm{yr}^{-1}$ ). There was also evidence of increased organic $\mathrm{C}$, total $\mathrm{N}$ and $\mathrm{P}$, available $\mathrm{N}, \mathrm{P}$ and $\mathrm{K}$, microbial biomass $\mathrm{C}$ and $\mathrm{N}$ in the soil of the improved system. A positive relationship between soil available $\mathrm{P}$ and soil organic $\mathrm{C}$ suggested that application of $\mathrm{P}$ to Vertisols increased carbon sequestration by $7.4 \mathrm{t} \mathrm{Cha}^{-1}$ and, in turn, the productivity of the legume-based system, thus ultimately enhancing soil quality.
\end{abstract}

Keywords: Vertisol, soil quality, carbon sequestration, semiarid tropics, watershed management, P fertilization

\section{INTRODUCTION}

$\mathrm{T}$ he semiarid tropics (SAT) includes those regions of the world where rainfall exceeds potential evapotranspiration for only 2-4.5 months of the year (dry SAT) or 4.5-7 months (wet SAT) with a mean annual temperature in either case of $>18^{\circ} \mathrm{C}$ (Troll 1965). The SAT is spread over 55 less developed countries covering approximately 11 million square kilometres. Much of the regions are densely populated and home for about 1.4 billion $\left(10^{9}\right)$ people, of which 560 million are rural poor (Ryan \& Spencer 2001). Approximately one-tenth of the SAT area ( 170 million ha) is located in India. Nutrient depletion is a major form of degradation in soils managed by poor farmers who cannot, or do not, use chemical fertilizers (Stoorvogel et al. 1993). In these areas there is a large spatial and temporal variability in rainfall, resulting in periods of excess soil moisture and of moisture deficit during the crop growing season (El-Swaify et al. 1985). Although several soil and agroclimatic factors such as soil type and infiltration rate affect soil runoff in the

${ }^{1}$ International Crops Research Institute for the Semi-Arid Tropics (ICRISAT), Patancheru, 502 324, AP, India. ${ }^{2}$ Natural Resources Conservation Services, United States Department of Agriculture (USAID), PO Box 2890, Washington DC 20013-2890, USA.

*Corresponding author. Fax: +91 40 23241239, E-mail: s.wani@cgiar.org event of high intensity rainfall, a large portion of the rainfall received is lost as surface runoff, which carries away nutrient-rich fine topsoil, causing soil degradation.

Sustainable agriculture involves the successful management of agricultural resources to satisfy human needs, while maintaining or enhancing the quality of the environment and conserving natural resources. Application of plant nutrients (Vlek 1990; Glendining \& Powlson 1995; Paustian et al. 1997c) and organic amendments, and diversification of monocropped cereals through inclusion of legumes, favour improvement of soil quality and build up of soil carbon (C). This leads to increased crop yields and consequently the amount of residues available to be returned to the soil (Wani et al. 1994a; Paustian et al. 1997b). Legumes improve soil fertility because of their nitrogen $(\mathrm{N})$ fixing ability, thus sparing indigenous soil $\mathrm{N}$ (Giller \& Wilson 1991; Wani et al. 1995a). Legumes are grown as intercrops or in rotation with cereals in the SAT and have been important components of sustainable farming systems since ancient times. Legumes often increase the yield of a subsequent cereal crop grown on the same soil compared with the yield of a cereal grown after a non-legume crop (Peoples \& Crasswell 1992; Kumar Rao et al. 1996). In addition to direct effects of fertilizer application on soil quality, high $\mathrm{N}$ availability may also enhance the formation 
of recalcitrant humic substances in soil (Fog 1988). Any management practice that increases the productivity of a crop directly influences the soil quality, provided the extra residues are returned to the soil.

In SAT agro-ecosystems, the primary constraint on productivity is water. The sustainability of Vertisol catchments through adoption of integrated catchment management (Virmani et al. 1989) have been studied at the International Crops Research Institute for the Semi-Arid Tropics (ICRISAT), Patancheru, India, since 1976. These long-term catchment experiments have provided an opportunity to validate the hypothesis that improved management of Vertisols not only increases crop productivity, but also increases $C$ sequestration and soil quality. The specific objectives of this study were to compare crop productivity and soil quality in long-term experiments that include traditional and improved management of Vertisols.

\section{MATERIALS AND METHODS}

\section{Site, soils and experimentation}

The experiments were conducted in two adjacent Vertisol catchments (3.45 ha BW 1 field and 3.15 ha in BW 4C field) at ICRISAT Centre, Patancheru, near Hyderabad, India $\left(17^{\circ} 36^{\prime} \mathrm{N}, 78^{\circ} 16^{\prime} \mathrm{E}, 545 \mathrm{~m}\right.$ altitude). The area receives $800 \mathrm{~mm}$ average annual rainfall; the average minimum temperature is $19^{\circ} \mathrm{C}$ and maximum temperature $32^{\circ} \mathrm{C}$. Rainfall is variable spatially and temporally and also occurs in torrential downpours. Such erratic rainfall results in spells of excess moisture and drought during the cropgrowing period. Also, there is variability in runoff, soil moisture and surface drainage. The soils in the watersheds are classified as Kasireddipalli series, Typic Pellusterts. Two systems (improved and traditional) were studied under longterm experiments initiated in 1976.

Improved system $(B W 1)$. An integrated watershed management system with a broad-bed and furrow (BBF) landform treatment (El-Swaify et al. 1985) was followed. The beds were $1.2 \mathrm{~m}$ wide with a $0.3 \mathrm{~m}$ furrow prepared at $0.4-0.6 \%$ gradient using a bullock-drawn bed-maker mounted on a tropicultor (El-Swaify et al. 1985). The land was cultivated soon after harvesting of the post-rainy season crop and after unseasonal rains the beds were formed again. Field traffic was confined to the furrows. Excess rainfall drained along the furrows and discharged into grassed waterways. Improved high-yielding varieties were dry-sown on a bed with a spacing of $1.5 \times 0.15 \mathrm{~m}$ for pigeon pea (Cajanus cajan) ICP 1-6, $0.9 \times 0.1 \mathrm{~m}$ for sorghum (Sorghum bicolor) $\mathrm{CSH} 9$, and $0.75 \times 0.20 \mathrm{~m}$ for maize $($ Zea mays $) \mathrm{DH}$ 103 at a depth of $50-70 \mathrm{~mm}$ during the period 8-15 June each year. Sixty $\mathrm{kg} \mathrm{N} \mathrm{ha}^{-1}$ and $20 \mathrm{~kg}$ phosphorus $(\mathrm{P}) \mathrm{ha}^{-1}$ as urea and di-ammonium phosphate (DAP), respectively, were applied in rows with a seed and fertilizer drill. Generally, monsoon rain arrives on or after 15 June at Patancheru.

The field was treated as a single plot from 1976 to 1988 . A two-year rotation was followed with sorghum intercropped with pigeon pea ( $2: 1$ proportion) and maize during the rainy season followed by chickpea (Cicer arientinum) (Annigeri) in the post-rainy season. From 1989 to 1998 the field was divided into two plots and a two-year rotation with sorghum ICSV 745 intercropped with pigeon pea ICP 1-6 in one year and in the next year greengram (Vigna radiata) PS 16 in the rainy season followed by sorghum CSH 9 in the post-rainy season. The two plots were treated as mirror images. Weed control was carried out by mechanical weeding once, using the tropicultor, and two hand weedings. Appropriate pest and disease management options were implemented as required. Sorghum was harvested by cutting the plants at $150 \mathrm{~mm}$ from ground level, leaving the stubbles in the field, thus conserving soil moisture. The stalks were dried and the plant dry matter weight was recorded. Pigeon pea was harvested at the end of February. In each plot from two replicates, an area of $12 \mathrm{~m}^{2}$ from each replicate was used for recording yield parameters. Immediately after the harvest of pigeon pea, the land was ploughed and left fallow. When summer rains occurred, the beds were reshaped for sowing of the next rainy season crops.

Traditional system ( $B W 4 C$ ). From 1976 to 1988 the land was left as cultivated bare fallow (to keep it weed-free) during the rainy seasons and sorghum was grown as sole crop in the post-rainy seasons (Virmani et al. 1989). From 1989 the field was divided into two plots, with a two-year rotation of bare fallow/sorghum (M 35-1) followed by bare fallow/chickpea (Annigeri) in the next year. The two plots were treated as mirror images. Seeds were sown with a local seed drill on a flat surface when seedbed moisture was adequate. No inorganic fertilizers were applied to the crop, but $10 \mathrm{tha}^{-1}$ of farmyard manure (FYM) was broadcast each alternate year before land preparation. Sorghum was intercultivated once, and then hand weeded. The land was ploughed every two years; harrowing was done with a blade harrow to control weeds. Dry matter yields were recorded each year.

\section{Soil sampling}

After a 24-year experimental cycle, both catchments (BW 1 and BW 4C) were sampled in April 1998 for detailed chemical and biological analysis of soil. Two replicates were sampled in each catchment. From each replicate four pooled samples were collected from points lying diagonally across the experimental plot. Each pooled sample consisted of samples taken at four points around each position on the diagonal. At each sampling position, cores were taken to $1.2 \mathrm{~m}$ depth at increments of $150 \mathrm{~mm}$. Soil cores for each depth were pooled, mixed well and used for analysis. In all, 8 pooled samples from each catchment were analysed. The samples from BW 1 were collected from the centre of beds. Table 1 gives details of the chemical and biological determinations.

\section{Statistical analysis}

Soil chemical and biological data obtained from catchments BW 1 and BW 4C were analysed using the analysis of variance method in GENSTAT 5 with management systems as main treatments and soil depths as sub-treatments. The significant differences between main and sub-treatments and interaction effects were studied by comparing the ' $F$ ' test of significance and standard error of means (Panse \& Sukhatme 1985). 
Table 1. Properties determined on air-dried soil samples passed through a 2-mm sieve.

\begin{tabular}{lll}
\hline Property & \multicolumn{1}{c}{ Test } & \multicolumn{1}{c}{ Reference } \\
\hline pH & Soil to water ratio $1: 2$ & Jackson 1973 \\
Organic C & Dichromate oxidation & Nelson \& Sommers 1982 \\
Total N & Modified Kjeldahl digestion & Dalal et al. 1984 \\
Mineral N & Steam distillation with $\mathrm{MgO}_{\text {and Devarda's alloy }}$ & Jackson 1973 \\
Available P & Extracted by 0.5 $\mathrm{M} \mathrm{NaHCO}_{3}$ & Olsen \& Sommers 1982 \\
Microbial biomass C and N & Chloroform-fumigation and incubation & Jenkinson \& Powlson 1976; Jenkinson 1988; Wani et al. 1994a \\
Bulk density & Core method & Blake \& Hartge 1986 \\
\hline
\end{tabular}

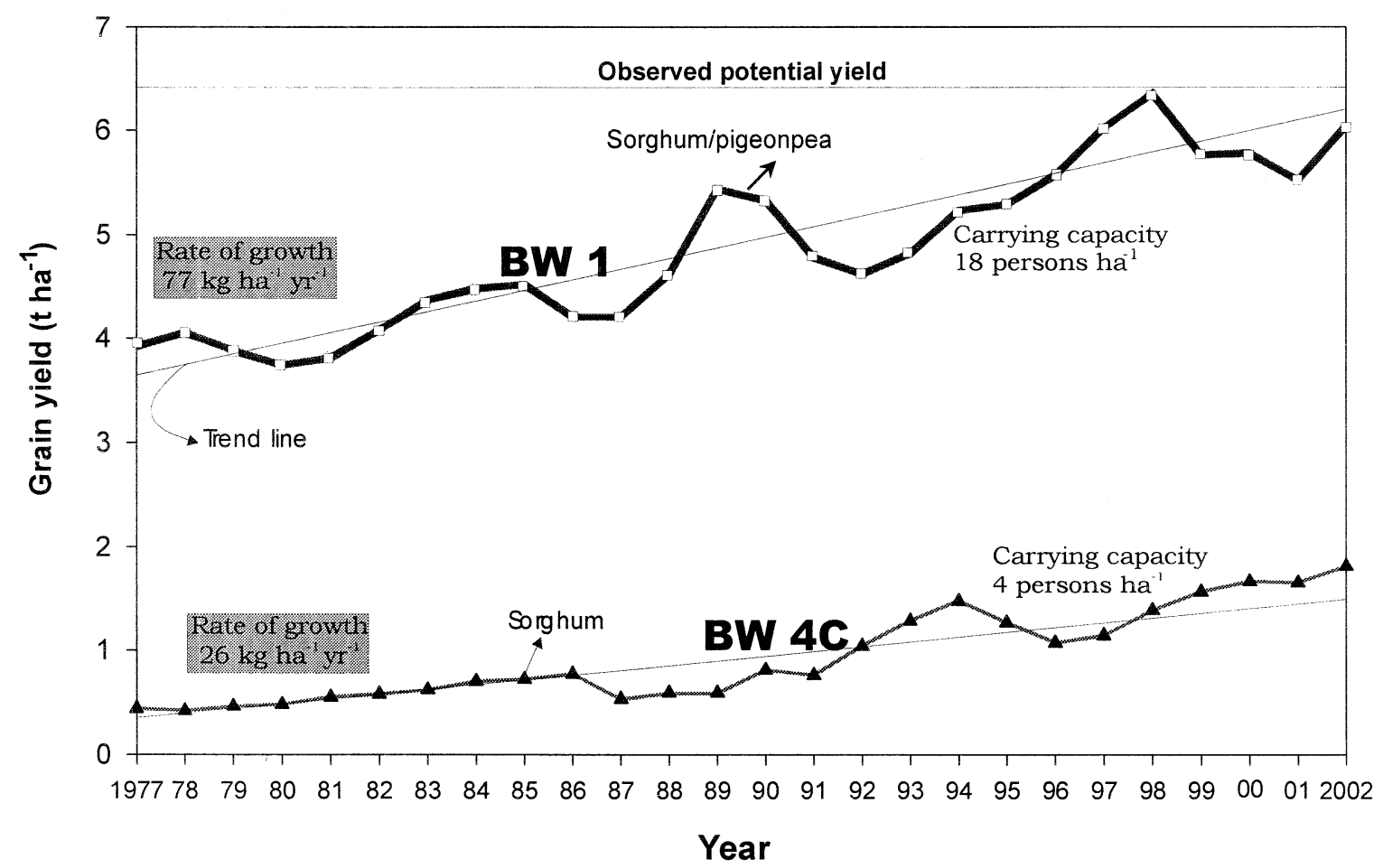

Figure 1. Three-year moving average of sorghum and pigeon pea grain yield under improved (BW 1 field) and traditional (BW 4C field) technologies in a deep Vertisol catchment at ICRISAT, Patancheru, India.

\section{RESULTS AND DISCUSSION}

Increased productivity

Grain yields were higher in the improved system than in the traditional system. Sorghum and pigeon pea together recorded an average grain yield of $4.7 \mathrm{tha}^{-1} \mathrm{yr}^{-1}$ compared with the $0.9 \mathrm{t} \mathrm{ha}^{-1} \mathrm{yr}^{-1}$, average yield of sole sorghum in the traditional system (Figure 1). In 1986 the sorghum in the traditional system failed due to inadequate soil moisture during the post-rainy season. The annual gain in grain yield in the improved system was $77 \mathrm{~kg} \mathrm{ha}^{-1} \mathrm{yr}^{-1}$ compared with $26 \mathrm{~kg} \mathrm{ha}^{-1} \mathrm{yr}^{-1}$ in the traditional system (Figure 1). Increased productivity of the improved system was partly due to improved soil fertility contributed by legumes. Beneficial effects of legumes on cereal yields following sole cropped legumes were similar to those reported by Peoples \& Crasswell (1992). Their yield increases ranged from 0.5 to $3 \mathrm{tha}^{-1}$, representing around $30-350 \%$ increase over yields of cereal/cereal sequences. Similar increases in system productivity were observed for sorghum/pigeon pea inter- cropping in this project. Further, the cowpea (Vigna unguiculata)/pigeon pea intercrop system provided more than $40 \mathrm{~kg} \mathrm{Nha}{ }^{-1}$ to the succeeding sorghum crops, producing $3.3 \mathrm{tha}^{-1}$ sorghum grain yield without $\mathrm{N}$ fertilizer (Rego \& Seeling 1996). The improved system of BBF landform reduced runoff from $220 \mathrm{~mm}$ measured within the traditional systems to $91 \mathrm{~mm}$, improving soil water content and reducing soil losses from $6.64 \mathrm{tha}^{-1}$ to $1.5 \mathrm{tha}^{-1}$ (ElSwaify et al. 1985, Wani et. al. 2000). The gain in grain productivity observed in the traditional system is attributed to the organic fertilizers (FYM) incorporated into the system and the sorghum stubble residue.

The yield increase in the improved system reported during this study cannot be attributed to a single factor, but to a combination of improved cropping and soil and water management practices. For example, inclusion of legumes in the cropping system improved soil fertility and sorghum yields through increased $\mathrm{N}$-fixation, increased biological activity and increased availability of nutrients other than $\mathrm{N}$ (Giller et al. 1995; Wani et al.1995a, b). 
The potential of high-yielding varieties used in the improved system cannot be realized with the natural reserves of nutrients in most soils. Hence, inorganic fertilizers were used in this study to augment the soil reserves.

\section{Soil chemical properties}

Our findings show that the improved system not only increased crop productivity, but also increased soil organic C content, total $\mathrm{N}$, and available $\mathrm{N}$ and Olsen $\mathrm{P}$ (Table 2). Using soil bulk densities of BW $1\left(1.19-1.47 \mathrm{~g} \mathrm{~cm}^{-3}\right)$ and

Table 2. Biological and chemical properties of semiarid tropical Vertisols in 1998 after 24 years of cropping under improved and traditional systems in catchments at ICRISAT Center, Patancheru, India.

\begin{tabular}{|c|c|c|c|c|}
\hline \multirow[t]{2}{*}{ Properties } & \multirow[t]{2}{*}{ System } & \multicolumn{2}{|c|}{ Soil depth $(\mathrm{cm})$} & \multirow[t]{2}{*}{$\mathrm{SE} \pm$} \\
\hline & & $0-60$ & $60-120$ & \\
\hline \multirow{2}{*}{$\begin{array}{l}\text { Soil respiration } \\
\left(\mathrm{kg} \mathrm{Cha}^{-1}\right)\end{array}$} & Improved & 723 & 342 & \multirow[t]{2}{*}{7.8} \\
\hline & Traditional & 260 & 98 & \\
\hline \multirow{2}{*}{$\begin{array}{l}\text { Microbial biomass C } \\
\left(\mathrm{kg} \mathrm{Cha}^{-1}\right)\end{array}$} & Improved & 2676 & 2137 & \multirow{2}{*}{48.0} \\
\hline & Traditional & 1462 & 1088 & \\
\hline \multirow{2}{*}{$\begin{array}{l}\text { Organic carbon } \\
\left(\mathrm{t} \mathrm{Cha}^{-1}\right)\end{array}$} & Improved & 27.4 & 19.4 & \multirow[t]{2}{*}{0.89} \\
\hline & Traditional & 21.4 & 18.1 & \\
\hline \multirow{2}{*}{$\begin{array}{l}\text { Mineral N } \\
\left(\mathrm{kg} \mathrm{Nha}^{-1}\right)\end{array}$} & Improved & 28.2 & 10.3 & \multirow[t]{2}{*}{2.88} \\
\hline & Traditional & 15.4 & 26.0 & \\
\hline \multirow{2}{*}{$\begin{array}{l}\text { Net } \mathrm{N} \text { mineralization } \\
\left(\mathrm{kg} \mathrm{N} \mathrm{ha}^{-1}\right)\end{array}$} & Improved & -3.3 & -6.3 & \multirow[t]{2}{*}{4.22} \\
\hline & Traditional & 32.6 & 15.4 & \\
\hline \multirow{2}{*}{$\begin{array}{l}\text { Microbial biomass } N \\
\left(\mathrm{~kg} \mathrm{Nha}^{-1}\right)\end{array}$} & Improved & 86.4 & 39.2 & \multirow[t]{2}{*}{2.3} \\
\hline & Traditional & 42.1 & 25.8 & \\
\hline \multirow{2}{*}{$\begin{array}{l}\text { Non-microbial organic } \mathrm{N} \\
\left(\mathrm{kg} \mathrm{Nha}^{-1}\right)\end{array}$} & Improved & 2569 & 1879 & \multirow[t]{2}{*}{156.9} \\
\hline & Traditional & 2218 & 1832 & \\
\hline \multirow{2}{*}{$\begin{array}{l}\text { Total N } \\
\left(\mathrm{kg} \mathrm{Nha}^{-1}\right)\end{array}$} & Improved & 2684 & 1928 & \multirow[t]{2}{*}{156.6} \\
\hline & Traditional & 2276 & 1884 & \\
\hline \multirow{2}{*}{$\begin{array}{l}\text { Olsen } \mathrm{P} \\
\left(\mathrm{kg} \mathrm{Pha}^{-1}\right)\end{array}$} & Improved & 6.1 & 1.6 & \multirow[t]{2}{*}{0.36} \\
\hline & Traditional & 1.5 & 1.0 & \\
\hline
\end{tabular}

${ }^{\mathrm{a}} \mathrm{SE}=$ Standard error of mean.
BW 4C $\left(1.29-1.56 \mathrm{~g} \mathrm{~cm}^{-3}\right)$ to convert percentage $\mathrm{C}$ to amounts of soil $\mathrm{C}$ in the soil profiles, we estimated that an additional quantity of $7.3 \mathrm{tCha}^{-1}\left(335 \mathrm{~kg} \mathrm{Cha}^{-1} \mathrm{yr}^{-1}\right)$ was sequestered in soil under the improved system compared with the traditional system over the 24-year period (Table 2). According to Bruce et al. (1999), with the adoption of best management practices, a gain of $200 \mathrm{~kg} \mathrm{C} \mathrm{ha}^{-1} \mathrm{yr}^{-1}$ was observed on pastures and rangelands of the USA. The C inputs were found to increase with continuous cropping, particularly where fertilizers were applied and when legumes were included in the system (Wani et al. 1994a; Paustian et al. 1997a). With an increase in biomass C (89\%) there was an $83 \%$ increase in mineral $\mathrm{N}, 105 \%$ increase in microbial biomass $\mathrm{N}$ and about $18 \%$ increase in total $\mathrm{N}$ in the improved system compared with the traditional system. Net $\mathrm{N}$ mineralization in the improved system was found to be negative, indicating immobilization of $\mathrm{N}$ and the availability of the organic matter for microbial growth (Table 3).

Analysis of Olsen $\mathrm{P}$ content indicated that more available $\mathbf{P}$ was present in the improved system than the traditional system. The extent of available $\mathrm{P}$ was greater in rotations with legumes and further inquiry into the relation between legume-based rotations and dynamics of $\mathrm{P}$ is warranted (Wani et al. 1994a). The linear regression between available $\mathrm{P}$ and soil respiration $\left(R^{2}=0.905\right)$, microbial biomass $\left(R^{2}=0.634\right)$ and organic C $\left(R^{2}=0.731\right)$ was found to be significant (results not presented).

\section{Soil biological properties}

Soil microbial biomass is known to be both a source and a sink for nutrients, that is, the soils with more biomass will be able to release nutrients more rapidly, and with an increase in microbial biomass the availability of $\mathrm{N}$ and $\mathrm{P}$ in soils is increased. This is reflected in increased productivity and an improvement in soil quality. Soil microbial biomass responds more rapidly than soil organic matter as a whole to changes in management that alter the annual input of organic material into soil C (Powlson \& Jenkinson 1981). Thus changes in measured biomass can indicate trends in total organic matter content of the soil. Although small in mass, microbial biomass is one of the most labile pools of organic matter and thus serves as an important reservoir of

Table 3. Relative biological properties of soils from Vertisol catchments under improved system (IS) and traditional system (TS), April 1998, ICRISAT Center, Patancheru, India.

\begin{tabular}{|c|c|c|c|c|c|c|c|c|c|c|}
\hline \multirow[t]{2}{*}{ Description } & \multirow[t]{2}{*}{ System } & \multicolumn{9}{|c|}{ Soil depth $(\mathrm{cm})$} \\
\hline & & $0-15$ & $15-30$ & $30-45$ & $45-60$ & $60-75$ & $75-90$ & $90-105$ & $105-120$ & Mean \\
\hline \multirow[t]{2}{*}{ Microbial biomass $\mathrm{C}$ as $\%$ of organic $\mathrm{C}$} & IS & 9.1 & 11.3 & 9.7 & 9.1 & 11.9 & 8.4 & 11.7 & 12.1 & 10.3 \\
\hline & TS & 9.2 & 6.7 & 5.4 & 5.6 & 7.0 & 6.2 & 5.6 & 5.3 & 6.4 \\
\hline \multirow[t]{2}{*}{ Microbial biomass $\mathrm{N}$ as $\%$ of total soil $\mathrm{N}$} & IS & 3.1 & 4.1 & 3.1 & 2.5 & 2.7 & 1.7 & 1.5 & 2.0 & 2.6 \\
\hline & TS & 1.7 & 2.2 & 2.5 & 1.1 & 0.9 & 1.0 & 2.3 & 1.6 & 1.6 \\
\hline \multirow[t]{2}{*}{ Soil respiration $\left(\mu \mathrm{g} \mathrm{C} \mathrm{g}^{-1}\right.$ soil $\left.10 \mathrm{~d}^{-1}\right)$} & IS & 0.33 & 0.31 & 0.23 & 0.16 & 0.14 & 0.18 & 0.02 & 0.02 & 0.02 \\
\hline & TS & 0.27 & 0.12 & 0.10 & 0.06 & 0.06 & 0.04 & 0.01 & 0.01 & 0.01 \\
\hline \multirow[t]{2}{*}{ Net $\mathrm{N}$ mineralization $\left(\mathrm{mg} \mathrm{N} \mathrm{kg}^{-1}\right.$ soil $\left.10 \mathrm{~d}^{-1}\right)$} & IS & -1.4 & -0.8 & 0.5 & -0.2 & -0.3 & -0.9 & -1.1 & 0.9 & -0.2 \\
\hline & TS & 6.6 & 4.9 & 2.0 & 1.5 & 3.5 & 2.4 & 0.2 & 1.1 & 2.9 \\
\hline \multirow[t]{2}{*}{ Soil respiration $\left(\mu \mathrm{g} \mathrm{C} \mathrm{g}{ }^{-1}\right.$ microbial C $10 \mathrm{~d}^{-1}$ ) } & IS & 0.37 & 0.28 & 0.24 & 0.18 & 0.12 & 0.21 & 0.17 & 0.17 & 0.22 \\
\hline & TS & 0.22 & 0.19 & 0.17 & 0.10 & 0.09 & 0.07 & 0.10 & 0.11 & 0.13 \\
\hline
\end{tabular}


plant nutrients such as $\mathrm{N}$ and P (Jenkinson \& Ladd 1981; Marumato et al. 1982).

Biomass N comprised about $2.6 \%$ of total soil N (Table 3 ) in the improved system, whereas in the traditional system it constituted only $1.6 \%$. Microbial biomass $\mathrm{C}$ was about $10.3 \%$ of total soil organic $\mathrm{C}$ in the improved system compared with only $6.4 \%$ in the traditional system. Soil respiration, in terms of both soil $\mathrm{C}$ and microbial biomass $\mathrm{C}$, was observed to be higher in the improved system than the traditional system. The linear regression of biomass $C$ and organic $\mathrm{C}$ was found to be significant and positively correlated $\left(R^{2}=0.69\right)$ (results not presented). An increased proportion of organic $\mathrm{C}$ and total $\mathrm{N}$ in the form of biomass $\mathrm{C}$ and $\mathrm{N}$ in Vertisols (Table 2) under improved management helps to explain the increased $\mathrm{N}$ supplying capacity under pigeon pea based systems, as observed earlier by Wani et al. (1995b).

Biomass C, as a proportion of total soil C, serves as a surrogate for soil quality (Jenkinson \& Ladd 1981). In this study, improved management practices of Vertisols resulted in higher values (10.3 vs. $6.4 \%$ ) of biomass $\mathrm{C}$ as a proportion of soil organic C up to $120 \mathrm{~cm}$ soil depth, indicating that with improved management these Vertisols would reach a new stage of equilibrium. These results are supported by a continued increase of $77 \mathrm{~kg} \mathrm{ha}^{-1} \mathrm{yr}^{-1}$ grain yield over the last 26 years with improved management. The traditional system is also sustainable but at a lower production level $(1000 \mathrm{~kg}$ $\mathrm{ha}^{-1}$ ), which can support 4 persons $\mathrm{ha}^{-1} \mathrm{yr}^{-1}$, whereas the improved system can support about 18 persons ha $\mathrm{hr}^{-1}$ in an integrated watershed system (Figure 1).

Increased soil respiration in the improved system compared with the traditional system indicated increased biological activity leading to increased nutrient availability, as is evident from the results. An increase in biomass $\mathrm{C}$ resulted in a larger labile $\mathrm{N}$ pool for mineralization. At greater soil depth, microbial biomass was more abundant in the improved system than that in the traditional system. However, the differences between the improved and traditional systems were less (39 vs. $\left.26 \mathrm{~kg} \mathrm{~N} \mathrm{ha}^{-1}\right)$ for microbial biomass N. Additionally, there was an increase in microbial biomass $\mathrm{C}$ due to increased $\mathrm{C}$ substrate availability. Microbial biomass at deeper soil depths may be metabolically less active than biomass in surface layers, because of reduced availability of oxygen as a result of poor aeration under field conditions.

\section{CONCLUSIONS}

The results indicate that a crop rotation involving rainy season bare fallow accelerates the loss of soil organic $C$ in the traditional system compared with an improved system. Cropping systems involving legumes, land and water management factors, such as the broad-bed and furrow method and use of inorganic fertilizers, increase the organic matter content, available $\mathrm{N}$ and Olsen $\mathrm{P}$. More soil organic $\mathrm{C}$ is sequestered and the biological properties of the soil are improved, leading to higher crop production.

The nutrient inputs through commercial fertilizers in the form of $\mathrm{N}$ and $\mathrm{P}$ have increased the grain yields of the legume based system. The inclusion of legumes in the cropping system has increased soil $\mathrm{N}$ through biologically fixed N. All these factors have improved the ability of the vertisols in BW 1 to sequester $\mathrm{C}$ from the atmosphere. This gives strong evidence that SAT soils, which are nutrient deficient, could sustain and increase crop productivity along with improved soil quality. A major advantage in pursuing strategies to increase soil quality and increased C sequestration in Vertisols is that the increase in soil organic matter will also benefit agricultural productivity and sustainability.

The improved system reported here showed a positive influence on crop production, carrying capacity of land (both of men and animals) and soil quality. Even in the traditional system, where there was incorporation of FYM every two years, average annual gains of $26 \mathrm{~kg} \mathrm{ha}^{-1} \mathrm{yr}^{-1}$ were observed.

\section{ACKNOWLEDGEMENTS}

This paper is based on the long-term watershed experiments at ICRISAT Center, Patancheru. We acknowledge the help of all the scientists who have been associated with these experiments and in particular the assistance of Mr Mohan Reddy, Mr Sudi, Dr K. Sailaja and Dr K.L. Sahrawat.

\section{REFERENCES}

Blake GR \& Hartge KH 1986. Bulk density. In: Methods of soil analysis, Part I, 2nd edition, Physical and mineralogical methods, Agronomy No. 9, ed CA Black, American Society of Agronomy Madison WI USA pp $363-375$.

Bruce JP Frome M Haites E Janzen H Lal R \& Paustian K 1999. Carbon sequestration in soils. Journal of Soil and Water Conservation 9, 382-389.

Dalal RC Sahrawat KL \& Myers RJK 1984. Inclusion of nitrate and nitrite in the Kjeldahl nitrogen determination of soils and plant materials using sodium thiosulphate. Communications in Soil Science and Plant Analysis $15,1453-1461$.

El-Swaify SA Pathak P Rego TJ \& Singh S 1985. Soil management for optimized productivity under rainfed conditions in the semi-arid tropics. Advances in Soil Sciences 1, 1-63.

Fog K 1988. The effect of added nitrogen on the rate of decomposition of organic matter. Biological Reviews 63, 433-462.

Giller KE \& Wilson KJ 1991. Nitrogen fixation in tropical systems. CAB International Wallingford UK, $323 \mathrm{pp}$.

Giller KE Mc Donagh JF Thompson B \& Limpinuntana V 1995. Legumes in the cropping systems of northeast Thailand. In: Soil management in sustainable agriculture, eds HF Cook \& H Lee, Wye College Press Wye UK pp 95-103.

Glendining MJ \& Powlson DS 1995. The effects of long continued applications of inorganic nitrogen fertilizer on soil organic nitrogen - a review. In: Soil management - experimental basis for sustainability and environmental quality. Advances in Soil Science, eds R Lal \& BA Stewart, CRC Lewis Publishers Boca Raton FL USA pp 385-446.

Jackson ML 1973. Nitrogen determination for soils and plant tissue. In: Soil chemical analysis. Prentice Hall New Delhi India pp 183-205.

Jenkinson DS 1988. Determination of microbial biomass carbon and nitrogen in soil. In: Advances in nitrogen cycling in agricultural ecosystems, ed JR Wilson, CAB International Wallingford UK pp 368386.

Jenkinson DS \& Ladd JN 1981. Microbial biomass in soil: measurement and turnover. In: Soil biochemistry, Vol 5, eds EA Paul \& JN Ladd, Dekker New York USA pp 415-471.

Jenkinson DS \& Powlson DS 1976. The effects of biocidal treatments on metabolism in soil: V. A method for measuring soil biomass. Soil Biology and Biochemistry 8, 209-213.

Kumar Rao JVDK Wani SP \& Lee KK 1996. Biological nitrogen fixation. In: Dynamics of roots and nitrogen in cropping systems of the SAT. ICRISAT, India, 21-25 November 1994. Proceedings of the International Workshop, JIRCAS International Agriculture Series 
No. 3. Japan International Research Center for Agricultural Sciences Tsukuba Japan pp 322-334.

Marumato T Anderson JPE \& Domsch KH 1982. Mineralisation of nutrients from soil microbial biomass . Soil Biology and Biochemistry 14, 469-475.

Nelson DW \& Sommers LE 1982. Total carbon, organic carbon and organic matter. In: Methods of soil analysis. Part II, eds AL Page RH Miller \& DR Keeny, American Society of Agronomy Madison WI USA pp 539579 .

Olsen SR \& Sommers LE 1982. Phosphorus. In: Methods of soil analysis Part II, 2nd edition, eds AL Page RH Miller \& DR Keeney, American Society of Agronomy and Soil Science Society of America Madison WI USA pp 403-430.

Panse VG \& Sukhatme PV 1985. Statistical methods for agricultural workers, 4th enlarged edition. Indian Council of Agricultural Research New Delhi India 375 pp.

Paustian K Agren G \& Bosatta E 1997a. Modeling litter quality effects on decomposition and soil organic matter dynamics. In: Driven by nature: plant litter quality and decomposition, eds G Cadisch \& KE Giller, CAB International Wallingford UK pp 313-336.

Paustian K Andren O Janzen HH Lal R Smith G Tian H Tiesen M Van Noordwijk \& Woomer, P 1997b. Agricultural soil as a sink to offset $\mathrm{CO}_{2}$ emissions. Soil Use and Management 13, 230-244.

Paustian K Colins HP \& Paul EA 1997c. Management controls on soil carbon. In: Soil organic matter in temperate agro-ecosystems: long-term experiments in North America, eds EA Paul K Paustian ET Elliott \& CV Cole, CRC Press Boca Raton FL USA pp 15-49.

Peoples MB \& Crasswell ET 1992. Biological nitrogen fixation: investments, expectations and actual contributions to agriculture. Plant and Soil 141, 13-39.

Powlson DS \& Jenkinson DS 1981. A comparison of the organic matter, biomass, adenosine triphosphate and mineralizable nitrogen contents of ploughed and direct drilled soils. Journal of Agricultural Science, Cambridge 97, 713-721.

Rego TJ \& Seeling B 1996. Long-term effects of legume based cropping systems on soil nitrogen status and mineralization in Vertisols. In: Roots and nitrogen in cropping systems of the semi-arid tropics, eds $\mathrm{O}$ Ito $\mathrm{C}$ Johansen JJ Adu-Gyamfi K Katayama JVDK Kumar Rao \& TJ Rego,
Japan International Research Center for Agricultural Sciences Tsukuba Japan pp 603-614.

Ryan JG \& Spencer DC 2001. Challenges and opportunities: shaping the future of the semi-arid tropics and their implications. International Crops Research Institute for the Semi-Arid Tropics, Patancheru Andhra Pradesh 502324 India 83 pp.

Stoorvogel JJ Smaling EMA \& Janssen BH 1993. Calculating soil nutrient balances in Africa at different scales. I. Supra-national scale. Fertilizer Research 35, 227-235.

Troll C 1965. Seasonal climates of the earth. In: World maps of climatology, eds E Rodenwaldt \& H Jusatz, Springer-Verlag Berlin Germany pp 19-25.

Virmani SM Rao MR \& Srivastava KL 1989. Approaches to the management of Vertisols in the Semi-Arid Tropics: The ICRISAT Experience. In: Management of Vertisols for improved agricultural production: Proceedings of IBSRAM Inaugural Workshop, 18-22 February 1985, ICRISAT, Patancheru 502 324, India. International Crops Research Institute for the Semi-Arid Tropics Patancheru 502324 Andhra Pradesh India pp 17-33.

Vlek PLG 1990. The role of fertilizers in sustaining agriculture in subSaharan Africa. Fertilizer Research 26, 327-339.

Wani SP Mc Gill WB Haugen-Koyzra KL Robertson JA \& Thurstson JJ 1994a. Improved soil quality and barley yields with faba-beans, manure, forages, and crop rotation on a gray luvisol. Canadian Journal of Soil Science 74, 75-84.

Wani SP Rego TJ Rajeswari S \& Lee KK 1995a. Effect of legume-based cropping systems on nitrogen mineralisation potential of Vertisol. Plant and Soil 175, 265-274.

Wani SP Rupela OP \& Lee KK 1995b. Sustainable agriculture in the semi arid tropics through biological nitrogen fixation in grain legumes. Plant and Soil 174, 29-49.

Wani SP Singh P Pathak P \& Rego TJ 2000. Sustainable management of land resources for achieving food security in the semi-arid tropics. In: Advances in land resources management for 21st century, eds SP Gawande JS Bali DC Das TK Sarkar DK Das \& G Narayanamurthy, Angrakor Publishers New Delhi India pp 290-306.

Received July 2002, accepted after revision April 2003. 